Volume 01, No 02, Tahun 2018

ISSN: 2621-6612

Email: d3perinfokesunivet@gmail.com

Halaman: 25 - 28

\title{
PELATIHAN MANAJEMEN REKAM MEDIS SESUAI DENGAN STANDAR PEDOMAN PENYELENGGARAAN DAN PROSEDUR REKAM MEDIS DI PUSKESMAS KECAMATAN WERU KABUPATEN SUKOHARJO
}

\author{
Fahmi Hakam ${ }^{1}$, Fiqi Nurbaya ${ }^{2}$ \\ Prodi. Perekam dan Informasi Kesehatan, FKM, Universitas Veteran Bangun Nusantara ${ }^{(1,2)}$ \\ Email : fahmihakam01@gmail.com ${ }^{1}$, fiqinurbaya@ gmail.com ${ }^{2}$
}

\begin{abstract}
The aims of this research were to: 1) improve the quality of medical records and health workers related to health service facilities in order to be able to collect the data communicatively, 2) do the data collection correctly, 3) do the qualitative and quantitative analysis, 3) improve the management of medical record's work unit based on the applicable standard to produce information in gaining accurate medical information. The development of medical records worker's knowledge and competency in the local clinic was accompanied by the improvement of medical record's management in the local clinic.Dealing with the dedication for society, the implementer team used analysis study and gave the medical record workers intervention service in the local clinic. The service was held into two stages: 1) portraying the partners' characteristic, problems and needs of medical record workers in the local clinic, 2) giving intervention in the form of medical records management in the local clinic based on the applicable rule and standard. The interactive method was held in this service. The materials were theoretical and practical. The participants' ability was measured by Pre-Test dan Post-Test. The implementer team monitored and evaluated the training given. The results of dedication program in "Weru" Local Clinic: 1) the employee understood more about the "UKRM" management, 2) there were many problems regarding to the duplication of medical record number and the lack of quality and completeness, 3) the implementation of this activity got positive response from the head of local clinic and the participants (employee of UKRM).
\end{abstract}

\section{Keywords: Medical record, Local clinic, Training, Competency}

\begin{abstract}
ABSTRAK
Untuk meningkatkan kualitas tenaga perekam medis dan kesehatan pada sarana pelayanan kesehatan sehingga mampu melakukan pengumpulan data secara komunikatif. Selain itu juga mampu melakukan pendataan secara benar, melakukan analisis kuantitatif-kualitatif, perbaikan tata kelola manajemen unit kerja rekam medis sesuai dengan standar yang berlaku. Sehingga dapat menghasilkan sumber informasi dalam menghasilkan informasi kesehatan yang akurat. Adanya peningkatan pengetahuan dan kompetensi tenaga perekam medis di puskesmas, serta ada perbaikan manajemen pengelolaan rekam medis di puskesmas. Dalam Pengabdian Kepada Masyarakat ini tim pelaksana menggunakan analisa studi dan pemberian intervensi (pelatihan) kepada petugas rekam medis di Puskesmas, yang dilakukan dengan dua tahap, yaitu: 1) Menggambarkan karakteristik mitra, permasalahan dan kebutuhan dari tenaga rekam medis di Puskesmas. 2) Memberikan intervensi berupa pelatihan tentang manajemen rekam medis di Puskesmas sesuai standar dan peraturan yang berlaku. Metode pelatihan dilakukan dengan interaktif, penyampaian materi (Teori dan Praktik) dan mengukur kemampuan peserta dengan : Pre-Test dan Post-Test. Serta melakukan monitoring dan evaluasi pemberian pelatihan. Hasil dari pelaksanaan pengabdian di puskesmas weru : 1) Petugas puskesmas sudah semakin memahami pengelolaan dan manajemen UKRM di puskesmas. 2) Masih banyak ditemukan permasalahan duplikasi No.RM, Kurangnya monitoring kualitas dan kelengkapan. 3)Pelaksanaan kegiatan ini mendapat respon yang baik dari kepala puskesmas dan para peserta yang merupakan petugas di UKRM.
\end{abstract}

Kata kunci : Rekam Medis, Puskesmas, Pelatihan, Kompetensi 


\section{PENDAHULUAN}

Pusat Kesehatan Masyarakat, disingkat Puskesmas, adalah organisasi fungsional yang menyelenggarakan upaya kesehatan yang bersifat menyeluruh, terpadu, merata, dapat diterima dan terjangkau oleh masyarakat, dengan peran serta aktif masyarakat dan menggunakan hasil pengembangan ilmu pengetahuan dan teknologi tepat guna, dengan biaya yang dapat dipikul oleh pemerintah dan masyarakat. Upaya kesehatan tersebut diselenggarakan dengan menitikberatkan kepada pelayanan untuk masyarakat luas guna mencapai derajad kesehatan yang optimal, tanpa mengabaikan mutu pelayanan kepada perorangan (Sutisna 2011).

Puskesmas Kecamatan Weru merupakan unit pelaksana teknis kesehatan di bawah supervisi Dinas Kesehatan Kabupaten Sukoharjo. Secara umum, mereka harus memberikan pelayanan preventif, promotif, kuratif sampai dengan rehabilitatif baik melalui upaya kesehatan perorangan (UKP) atau upaya kesehatan masyarakat (UKM).

Berdasarkan Peraturan Menteri Kesehatan No 269/ Menkes/ Per/ III/ 2008 menyatakan bahwa Rekam Medias adalah berkas yang berisikan catatan dan dokumen tentang identitas pasien, pemeriksaan, pengobatan, tindakan dan pelayanan yang telah diberikan kepada pasien (Kementrian Kesehatan RI 2008).

Rekam medis mempunyai tujuan yakni dan mempunyai banyak aspek didalamnya aspek administrasi, hukum, keuangan, Pengabdian Kepada Masyarakat, pendidikan serta dokumentasi. Dengan banyak aspek yang dimiliki maka pengelolaan manajemen rekam medis yang baik adalah hal sudah seharusnya dilakukan oleh rumah sakit (Nurcahyo 2013).

Manajemen rekam medis dan informasi kesehatan adalah upaya pemeliharaan, pengelolaan dan manajemen dokumen rekam medis/ kesehatan, baik dengan cara konvensional (paperbased), maupun dengan berbasis elektronik di setiap fasilitas pelayanan kesehatan (Puskesmas). Pada implementasinya bidang ini memberikan kontribusi yang besar terhadap sistem pelayanan kesehatan dan peningkatan mutu dalam pelayanan kesehatan (Hakam 2016).

Persyararatan Akreditasi mempunyai fungsi dan tujuan sarana Pelayanan Kesehatan yang menyelenggarakan pelayanan berupa pelayanan rawat jalan, pelayanan rawat inap, Unit Gawat Darurat, pelayanan rujukan yang mencakupi pelayanan Rekam Medis dan penunjang medis serta dimanfaatkan untuk pendidikan, pelatihan, dan penelitian bagi para tenaga kesehatan di Puskesmas (Susanto \& Sukadi 2011).

Selain melakukan pencatatan data rekam medis, tenaga perekam medis juga dituntut untuk bisa melakukan analisis data dan menyajikan data dalam bentuk informasi kesehatan yang handal, sehingga bisa menjadi masukan bagi pejabat pengambil keputusan di puskesmas atau institusi kesehatan yang lainnya. Sehingga dengan hal ini, rekam medis merupakan hal penting dalam pengembangan layanan puskesmas. Selain hal tersebut, rekam medis juga berfungsi sebagai perlindungan kepentingan hukum baik bagi pasien, tenaga kesehatan maupun institusi pelayanan.

Berdasarkan analisis masalah yang didapatkan, bahwa hampir $80 \%$ petugas Rekam Medis di Puskesmas Kab. Sukoharjo bukan berlatar belakang dari pendidikan Rekam Medis. Kebanyakan dari mereka, adalah lulusan SMP, SMA dan lulusan dari D3/S1 Non-Rekam Medis. Sedangkan hanya $20 \%$ saja, petugas di Unit Rekam Medis yang berlatar belakang pendidikan D3 Rekam Medis. Pengelolaan dan manajemen rekam medis yang kurang optimal, menyebabkan pencatatan dan pelaporan menjadi terhambat, sehingga berpengaruh juga terhadap pelayanan yang diberikan.

Kemampuan pengelolaan dengan manajemen yang rapi, pengkodean yang sistematis dan benar, serta update tentang manajemen informasi kesehatan menjadi salah satu syarat utama bagi petugas rekam medis yang handal dan professional. Maka dari itu, kami bertujuan untuk memeberikan pelatihan kepada petugas rekam medis di puskesmas

\section{METODE}

Kegiatan Sosialisasi dan Pelatihan Manajemen Rekam Medis Sesuai Dengan Standar Pedoman Penyelenggaraan dan Prosedur kepada Petugas Unit Kerja Rekam Medis (UKRM) di Puskesmas, dengan menggunakan metode diskusi interaktif antara fasilitator dan peserta kegiatan. 
Sasaran Pengabdian Kepada Masyarakat adalah Petugas Unit Rekam Medis di Puskesmas Weru. Karena berdasarkan analisis masalah yang didapatkan, bahwa hampir $80 \%$ petugas Rekam Medis di Puskesmas Kab. Sukoharjo bukan berlatar belakang dari pendidikan Rekam Medis. Kebanyakan dari mereka, adalah lulusan SMP, SMA dan lulusan dari D3/S1 Non-Rekam Medis. Sedangkan hanya 20\% saja, petugas di Unit Rekam Medis yang berlatar belakang pendidikan D3 Rekam Medis.

Karena tingkat pendidikan yang rendah, ketidak sesuaian kompetensi, kurangnya upgrade pengetahuan tentang keilmuan rekam medis, sehingga menyebabkan manajemen dan tata kelola, serta pelayanan di unit rekam medis menjadi kurang optimal

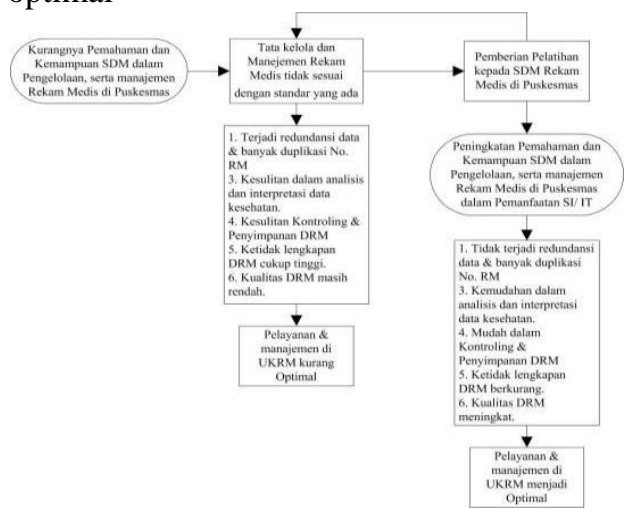

Gambar 1. Alur Kegiatan dan Kerangka Pemecahan Masalah

\section{HASIL}

Program pengabdian masyarakat yang dilakukan menekankan pada peningkatan pengetahuan kepada petugas rekam medis di puskesmas, terkait manajemen dan pengelolaan rekam medis yang baik dan benar. Maka dari itu, kegiatan pelatihan dilakukan dengan menggunakan pendekatan masalah yang ada di puskesmas dan kebutuhan SDM.

Adapun kegiatan pengabdian masyarakat yang dilakukan meliputi tahap persiapan dan pelaksanaan. Tahap persiapan SDM.

Penyusunan Materi dan persiapan tekknis. Tahap pelaksanaan terdiri dari pengkajian, perencanaan, implementasi, evaluasi dan rencana tindak lanjut

\section{PEMBAHASAN}

Dari hasil diskusi saat pelatihan dan pendampingan, diperoleh beberapa poin yang menjadi masalah utama di unit kerja rekam medis, diantaranya : Kurangnya pengetahuan petugas UKRM di puskesmas tentang manajemen pengelolaan rekam medis yang benar, banyaknya duplikasi No.RM, kurangnya monitoring kualitas dan kelengkapan, ketidaksesuaian kompetensi para petugas UKRM di puskesmas, disebabkan karena kurangnya jumlah lulusan dari tenaga perekam medis. Sehingga mengakibatkan manajemen rekam medis menjadi kurang optimal.

Kegiatan pelatihan manajemen rekam medis dan informasi kesehatan, berupa pengantar manajemen RM di puskesmas, pengelolaan

UKRM, struktur isi dan desain formulir, klasifikasi kodefikasi penyakit dan mutu dokumen rekam medis. Kegiatan pelatihan ini diikuti $90 \%$ petugas di unit rekam medis puskesmas weru, karena sebagiannya harus tetap bertugas di pelayanan.

Pelaksanaan kegiatan ini mendapat respon yang baik dari kepala puskesmas dan para peserta yang merupakan petugas di UKRM. Antusiasme ini, diwujudkan dalam bentuk keinginan dari kepala puskesmas weru, bahwa ke depannya dapat diadakan kegiatan pengabdian masyarakat yang berkelanjutan dan sesuai dengan kebutuhan puskesmas weru, terkait pengembangan tata kelola manajemen rekam medis.

Para peserta juga menginginkan ada materi pelatihan tingkat lanjut, sehingga pemahaman dan ilmu mereka, tentang manajemen rekam medis di puskesmas bisa up to date dan dapat digunakan untuk memperbaiki manajemen dan tata kelola di UKRM.

\section{SIMPULAN}

Simpulan yang diperoleh dari kegiatan pengabdian masyarakat di puskesmas weru antara lain : Petugas puskesmas sudah semakin memahami pengelolaan dan manajemen UKRM di puskesmas, masih banyak ditemukan permasalahan duplikasi No.RM, kurangnya monitoring kualitas dan kelengkapan serta pelaksanaan kegiatan ini mendapat respon yang baik dari kepala puskesmas dan para peserta yang merupakan petugas di UKRM. Selain itu juga perlu dilakukan pendampingan dan upgrade materi manajemen UKRM di puskesmas yang terbaru, perlu dilakukan identifikasi lebih mendalam dan monitoring penanganan masalah, perlu adanya pelatihan manajemen rekam medis puskesmas tingkat lanjut sehingga sesuai dengan kebutuhan dan perkembangan tata kelola rekam medis di puskesmas. 


\section{DAFTAR PUSTAKA}

Hakam, F., 2016. Analisis, Perancangan dan Evaluasi Sistem Informasi Kesehatan. Yogyakarta: Gosyen Publishing.

Hakam, F., 2016. Analisis Penyediaan Rekam Medis Pasien Rawat Jalan Berdasarkan Standar Operasional Prosedur (SOP) Di Puskesmas X. Jurnal Manajemen Informasi dan Administrasi Kesehatan (JMIAK), Vol 01 No 012018.1 (1).

Kementrian Kesehatan RI, 2008. Permenkes No 269 Tahun 2008 Tentang Rekam Medis, Republik Indonesia.
Nurcahyo, A., 2013.

Pengembangan Sistem Informasi

Rekapitulasi Laporan Rekam Medis Rumah Sakit Kepada Dinas Kesehatan Kabupaten/ Kota Berdasar Ketentuan Kementrian Kesehatan. Jurnal Fakultas Rekayasa Industri Institute Teknologi Telkom Bandung, 2.

Susanto, G. \& Sukadi, 2011. Sistem Informasi Rekam Medis Pada Rumah Sakit Umum Daerah ( RSUD ) Pacitan Berbasis Web Base. Jurnal Sentra Penelitian Engineering dan Edukasi, 3(4), pp.18-24.

Sutisna, E., 2011. Manajemen Kesehatan, Teori dan Praktek di Puskesmas, Yogyakarta: Gadjah Mada University Press. 